OPEN ACCESS

Edited by:

Iker Irisarri,

University of Göttingen, Germany

Reviewed by:

Oliver Hawlitschek

University of Hamburg, Germany

*Correspondence:

Jan W. Arntzen

pim.arntzen@gmail.com

Specialty section:

This article was submitted to

Evolutionary and Population Genetics,

a section of the journal

Frontiers in Ecology and Evolution

Received: 21 November 2021

Accepted: 03 January 2022

Published: 10 February 2022

Citation:

Arntzen JW (2022) The Midwife

Toad Challenge After (Half) a Century.

Front. Ecol. Evol. 10:819542.

doi: 10.3389/fevo.2022.819542

\section{The Midwife Toad Challenge After (Half) a Century}

\author{
Jan W. Arntzen ${ }^{1,2 *}$ \\ ${ }^{1}$ Naturalis Biodiversity Center, Leiden, Netherlands, ${ }^{2}$ Sylvius Laboratory, Institute of Biology, Leiden University, Leiden, \\ Netherlands
}

The evolutionary biologist Paul Kammerer (1880-1926) purportedly demonstrated that environmentally induced character states are carried over to the next generation(s), therewith providing evidence for Lamarckian evolution. Kammerer's work is generally seen as contentious but has also been valued as daring and insightful, and Kammerer has been heralded as an academic forebear of epigenetics. Most of the more pertinent of Kammerer's experiments on amphibians and the sea squirt have either been invalidated by replications that failed, or have been dismissed as virtually impossible. An experiment on color pattern change in the fire salamander stands out because it has been confirmed, but only with data for within a generation, so that Kammerer's claim concerning the inheritance of acquired character states still awaits confirmation. To facilitate and encourage replicate studies, I draw attention to species and populations that would be most practical and promising to work with, for those that are into the challenge.

Keywords: epigenetics, fire salamander, Paul Kammerer, phenotypic plasticity, Arthur Koestler

\section{THE INHERITANCE OF ACQUIRED CHARACTER STATES AND PAUL KAMMERER}

The Lamarckian oriented experiments of the Austrian evolutionary biologist Paul Kammerer (1880-1926) continue to raise debate, with their performer alternatively portrayed as an outstanding scientist ahead of his time (Sermonti, 2000; Vargas, 2009; Vargas et al., 2017) or a highly strung perpetrator of fraud (Whittaker, 1985; van Alphen and Arntzen, 2016, 2017; see also Parnes, 2006; Senglaub, 2006), while others give him both some benefit and some doubt (Gliboff, 2005, 2006, 2010; Taschwer, 2016; Nahm, 2021). After a long period of silence following Kammerer's suicide, science writer Arthur Koestler placed Kammerer and his experiments back in the spotlight (Koestler, 1971) and, with that, the pertinent question of whether organismal evolution might, at least in part, proceed through the inheritance of acquired character states. Over the recent decades, this topic has gained in importance, with a refreshed attention on epigenetic modes of inheritance (Deichmann, 2016; Adrian-Kalchhauser et al., 2020; Anastasiadi et al., 2021). At the heart of the discourse is the discovery that animal cells fated for reproduction (the germ line) are already set apart during early development from other cells that form the body (the soma) (Weismann, 1892). On the basis of this separation, Weismann reasoned that new genetic properties acquired by somatic cells cannot be transmitted to the offspring - the "Weismann barrier." Kammerer's opponents were neo-Darwinians and argued fiercely against Lamarckian evolution based on Weismann's (and also Mendel's) theories in an acrimonious debate that lasted until after 
Kammerer's untimely death. For a gentle introduction to this early twentieth century dispute and to Kammerer, see Sir David Attenborough's “A curious hoax?” (Attenborough, 2013).

Kammerer's most notorious experiments concerned the sea squirt, Ciona intestinalis, as well as amphibian species in the genera Proteus (the blind cave salamander), Salamandra (fire salamanders) and Alytes (midwife toads). The call for replication of Kammerer's work has never dissipated (E. W. MacBride in Bateson, 1919; Svardal, 2010; Nahm, 2021, to name a few). It is, however, not always appreciated that the straightforward experiment on the sea squirt-purportedly demonstrating the inheritance of an acquired character state-was repeated three times, all with negative results (Fox, 1924; Wermel and Lopaschov, 1930; Whittaker, 1975; see also Weissmann, 2012; Jeffery, 2015). Even though this particular study was seen as most pertinent and crucial by Kammerer himself, it was never published other than in summary mode (Kammerer, $1915,1923,1924)$. For a description of the experiment on this deceptively simple looking organism and the different outcomes see Figure 1.

Kammerer's amphibian studies are briefly laid out below. I go through the works that put Kammerer's accomplishments to the test and comment upon the feasibility and relevance to further replicate these experiments. I do not focus on the possible wrongdoings of Kammerer, his victimhood from antisemitism or on his position as an early epigeneticist, because these topics distract from the main issue on the inheritance of acquired character states and, moreover, have been evaluated at length elsewhere (Gliboff, 2010; van Alphen and Arntzen, 2016, 2017; Taschwer, 2016).

\section{THE AMPHIBIAN EXPERIMENTS}

\section{Color Change and Eye Regeneration}

Kammerer observed that the blind cave salamander (Proteus anguinus) turned from the pigment-less coloration occurring in wild subterranean populations to a dark color if exposed to daylight and that darkened animals often produced dark offspring, irrespective of whether they were laid as eggs or born as metamorphosed young. He also showed that the salamanders developed relatively large, functional eyes if kept under some particular conditions of light (Kammerer, 1912, 1923).

\section{Mode of Reproduction}

Salamandra salamanders come in two different reproductive modes. The Alpine salamander ( $S$. atra) produces on land two young that resemble their parents. The offspring pass through embryonic and larval stages, but these occur unobserved inside the mother's uterus, where metamorphosis takes place before they are born (pueripatity). In the fire salamander (S. salamandra) the offspring also partially develop inside the uterus, but these are many and are generally deposited as aquatic larvae that have yet to undergo transformation (larviparity). Kammerer kept both species under environmental conditions typical for their counterpart species and noted that over their lifetime the individuals switched from a larviparous to a pueriparous mode of reproduction, and vice versa. The induced reversals of reproductive modes were subsequently observed in the next generation and considered to be inherited (Kammerer, 1904, 1907, 1923).

\section{Color Pattern Change}

The fire salamander is secretive yet conspicuous, with sulfur yellow spots or stripes on an intense black background. Kammerer kept metamorphosed fire salamanders in terraria furnished with yellow or black backgrounds and noted that the differential treatment had the effect that the salamanders turned increasingly yellow and black, respectively. The acquired character states were shown to be inherited in experiments covering three generations (Kammerer, 1910, 1913, 1923).

\section{Aquatic Breeding}

Midwife toads (genus Alytes) are terrestrial breeders in which the male carries the fertilized eggs in a string wrapped around its ankles (Figure 2). For excellent footage on the mating behavior of Alytes obstetricans see Redondo (2012). In an experiment covering six generations, Kammerer managed to make midwife toads reproduce in water, with male offspring developing seasonal nuptial pads in adulthood and with female fecundity increasing dramatically, which was associated with smaller egg sizes. These are features that are typical of aquatic breeders (Kammerer, 1906, 1909, 1919, 1923).

\section{REPLICATION}

The experiment on eye development in Proteus anguinus has been attempted by Jacques Durand, who remained more than a little doubtful of Kammerer's results. He reports: "Experiments were designed to find out if the presence of light will actually permit regeneration of eyes. Young specimens of Proteus were exposed to the action of daylight for 6.5 years. Others were exposed to artificial light of wave-lengths between 600 and 1,200 $\mathrm{nm}$ (i.e., within the red and infrared range of the spectrum). This continued for the first 10 years of age. After several years, individuals exposed to light become bluish-black. Over the same time, even if the eye is initially relatively well developed, the corneal ectoderm thickens, the lens diminishes in size and eventually disappears." (Durand, 1976, p. 462). It is widely known that $P$. anguinus may turn dark under conditions of light (e.g., von Chauvin, 1883; Schreiber, 1912), but a hereditary effect of such a treatment as reported by Kammerer remains to be confirmed. Moreover, Kammerer's observation that $P$. anguinus is facultatively life bearing has not been confirmed (Blackburn, 2019).

As for the fire salamander experiments, Kammerer's early work on a change in reproductive mode is said to have been confirmed (Koestler, 1971). This effort, however, only dealt with the raising of larvae that had been excised from gravid Alpine salamanders (Knoblauch, 1904), as had been previously shown to be tricky, but not impossible (von Chauvin, 1876, 1877). Experiments on color pattern change in the fire salamander are manifold, before as well as after Kammerer, inspired by his work or independently, but three stand out (von Frisch, 

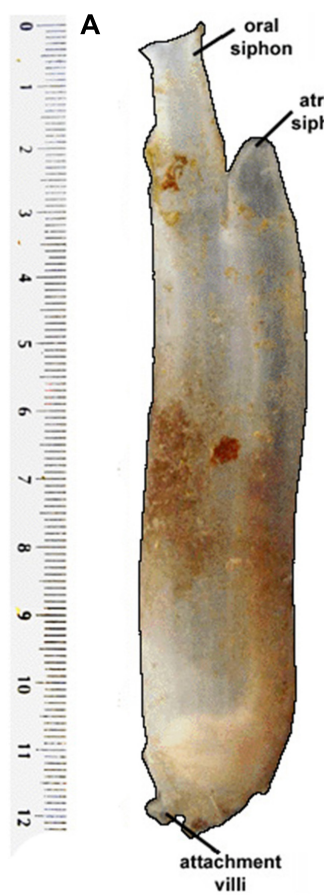
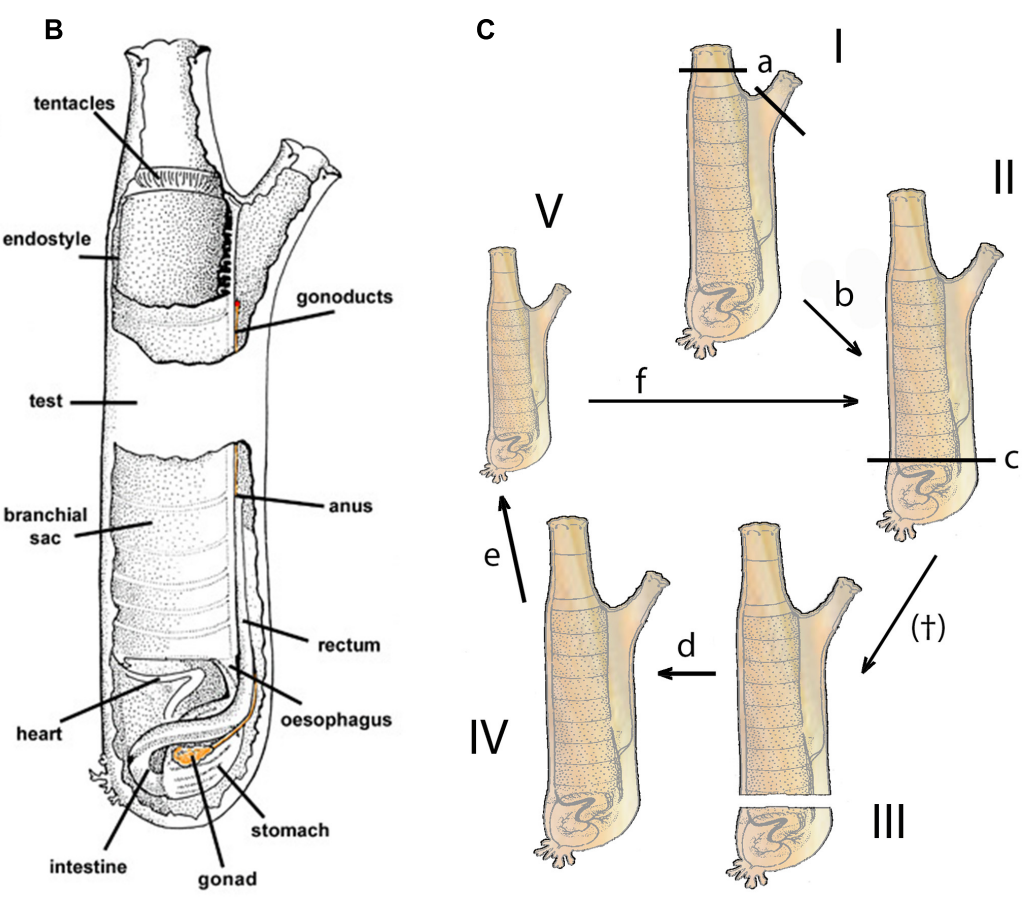

FIGURE 1 | Experiment on the inheritance of acquired character states in the sea squirt, Ciona intestinalis. To the left, external appearance and anatomy along with a cm scale (reproduced from Cirino et al., 2002, with permission) with (A) lateral view of an adult individual and (B) schematic dissection, obtained by removing part of the tubular body ("test"), showing the main anatomical structures of an adult. Gonads and gonoducts are colored. To the right, (C) sea squirt lifecycle, with a schematic representation of Kammerer's experimental protocol (after Whittaker, 1975; Jeffery, 2015). Amputation and regeneration of both siphons resulted in animals with longer siphons (I and II), bisection of long-siphoned animals (II) allowed the distal (top) half to regenerate a gonad (III and IV), animals with regenerated gonads were crossed and produced offspring with long siphons ( $\mathrm{V}$ and $\mathrm{V}$ ). Letters indicate the following events: a - siphon amputation, $b$ - siphon regeneration, $\mathrm{c}$-bisection, $\mathrm{d}$-regrowth of amputated proximal part, $\mathrm{e}$-fertilization and the production of offspring and $\mathrm{f}$-growth and maturation. The sea squirts either reproduced as in Kammerer's hands, or did not survive the gonad operation ( $\dagger$ ), as reported earlier by Hirschler (1914). Other investigators were unable to obtain longer siphons (b) after one or more cycles of amputation (Fox, 1924; Wermel and Lopaschov, 1930) and the regrowth and gonad regeneration could also not be repeated (Whittaker, 1975).

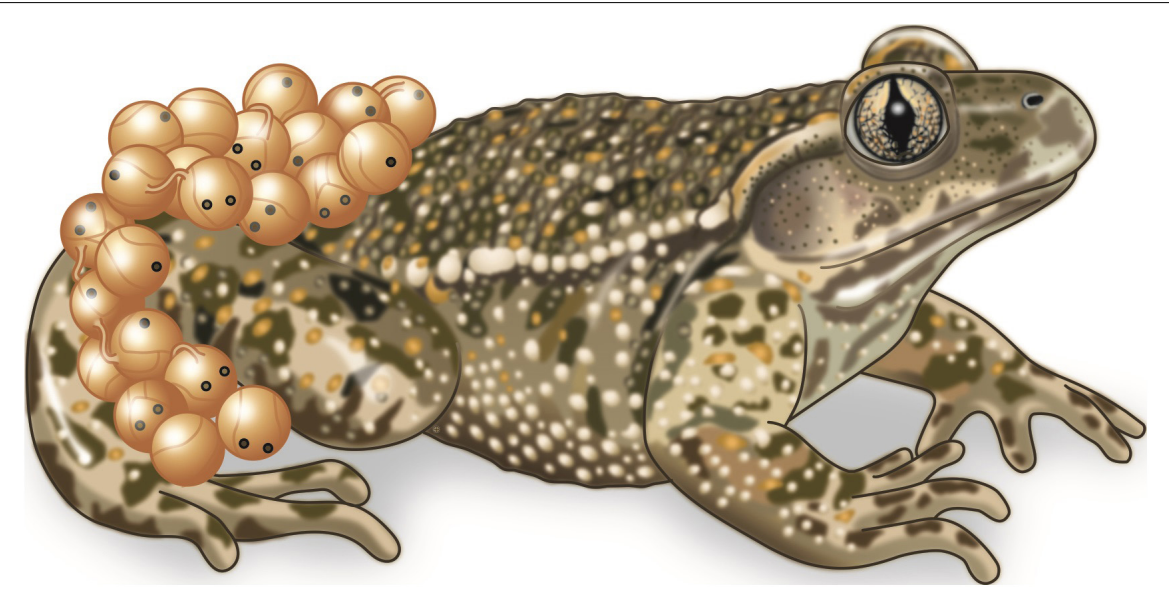

FIGURE 2 | Male midwife toad (Alytes obstetricans) carrying a string of developing embryos. Drawing by Bas Blankevoort, copyright Naturalis Biodiversity Center.

1920; Herbst, 1924; Sanchez et al., 2019). These three all reached the same general conclusion that larval and freshly metamorphosed fire salamanders do develop slightly different ratios of yellow and black coloration, depending on the color of the background at which they are raised. The question whether these experiments classify as genuine replicates is addressed by Nahm (2021). Either way, because observations are so far limited to within a generation, the crucial finding 
by Kammerer on the heritability of the induced color change awaits confirmation.

Among the wide variety of Kammerer's experiments, those dealing with the common midwife toad (Alytes obstetricans) attracted most attention, but as yet efforts to replicate this work did not proceed beyond the early stages (see e.g., "The unrepeatable experiment," Appendix 3 in Koestler, 1971). From a personal involvement, I present the outcome of a humble, serendipitous experiment. Back in the summer of 1977 I placed a small plastic bucket over a toad carrying developing embryos with the aim of photographing it in daylight. By morning this male had shed its egg-string, even though it had not even been touched. I later repeated the experiment to illuminate my MSc-supervisor, Dr. D. Hillenius, who had a keen interest in the Kammerer and Koestler debate and was thrilled by the thought that Kammerer might have secured some groundbreaking results. This time we used a plastic kitchen strainer instead of a bucket, to allow a little wind, moisture and light to pass through, but the result was the same, upon which Hillenius and myself agreed that carrying midwife toads are prone to stress, that Alytes obstetricans is not quite the laboratory animal one would choose and that replication of Kammerer's study would be a delicate, if not impossible, undertaking. It almost goes without saying that midwife toad "water eggs" or nuptial pads have not been experimentally produced, other than by Kammerer.

Critique on Kammerer's work took off in 1913, by one of his direct colleagues at the "Biologische Versuchsanstalt" research institution in Vienna (Megušar, 1914; see also Schultschik et al., 2017) and by geneticists abroad, such as Wilhelm Johannsen, who observed: "It is very characteristic for this researcher, that he always obtains so many positive results and that further testing provides nothing." (Johannsen, 1913, p. 449) and William Bateson who noted: "If we had certain assurance that even a single unimpeachable case could be repeated at will, the whole matter would assume a more serious aspect." (Bateson, 1913, p. 210). The most frequently suggested modus operandi for a mistaken or cheating Kammerer is that he presented individuals collected from nature as the result of his experiments, such as on the fire salamander by E. G. Boulenger in Bateson (1913, p. 208), on the sea squirt by Whittaker (1975) and van Alphen and Arntzen $(2016,2017)$ on the whole lot.

\section{PERSPECTIVES}

After more than a century of debate, most herpetologists and evolutionary biologists would accord with Bateson who, when provoked to replicate Kammerer's work, commented: "We, however, are likely to leave that task to those who regard it as a promising line of inquiry." (Bateson, 1919, p. 345). To "those" that are into the challenge nevertheless, it would seem ill-advised to put effort in experiments that have already been invalidated (Ciona, Proteus). Moreover, to extend the work on Proteus into the rearing and breeding of offspring would be a demanding undertaking due to the species' exceptionally long generation time and intermittent breeding (Voituron et al., 2011), launching a venture of several decades.

Replication of Kammerer's Salamandra experiments stands out as feasible and not quite inauspicious. Testing for the reversal of reproductive modes among fire and Alpine salamanders presents a blank canvas. With future experimental crosses among individuals that are genetically modified by environmental imprinting in mind, researchers may wish to divert their attention from $S$. atra to some recently discovered Iberian pueriparous lineages of the otherwise larviparous S. salamandra. Whereas hybridization of $S$. atra and $S$. salamandra is unlikely on account of their long-term evolutionary independence (since the Miocene; Burgon et al., 2021), the cross-breeding of larviparous and pueriparous forms of $S$. salamandra would seem feasible, considering that they have a most recent common ancestor at just ca. 10,000 years before present, as inferred from biogeographic and molecular genetic data (Velo-Antón et al., 2007, 2012; Lourenço et al., 2018). Another promising model is the larviparous/pueriparous $S$. salamandra fastuosa, also from the Iberian peninsula. This subspecies can alternatively bear numerous larvae or few metamorphosed young (Greven, 2003; Buckley et al., 2007) and, possessing a wider geographical range, may be easier to get hold of than the localized lineages mentioned above. It should yet be kept in mind though that Kammerer's own material was from central Europe (Kammerer, 1904 , p. 170-173) where S. salamandra is larviparous, as it is all over the species range, except for some lineages in the north of Spain.

The fire salamander color pattern change experiment also qualifies, but before embarking on this endeavor one might wish to take note of Richard Goldschmidt who, upon visiting Kammerer's laboratory, noted that "... the backgrounds of both types, supposed to be yellow and black, were in no way different from one another; both were a filthy, neglected gray!" (Goldschmidt, 1956, p. 166-167). Another word of caution comes from Kammerer himself who stated that the experiment would take one or two decades (Kammerer, 1913, p. 6-7), in a detailed protocol that by a contemporary colleague herpetologist was seen as designed to deter, rather than encourage replication (Werner, 1915). It may be concluded that an experimenter wishing to find a tractable model system to study transgenerational epigenetic effects would probably do better elsewhere. An alternative hypothesis is that Kammerer combined material from different subspecies to make his case, as by Boulenger's opinion mentioned above. Modern molecular genetic techniques would allow to disentangle salamander family relationships and geographical variation but, unfortunately, Kammerer's collection appears not to have survived the turbulences of twentieth century Europe, as indeed the author was not able to retrieve any of it (see section "Acknowledgments"). Finally, the midwife toad challenge seems awkward, unwieldy and altogether impossible. If taken forward nevertheless, it may be beneficial to turn to the species Alytes muletensis from Mallorca that breeds well in captivity (Tonge and Bloxam, 1989; Buley and Gonzalez-Villavicencio, 2000).

With one century passed since Kammerer's experiments, and half a century since Koestler's booklet, no data have come to 
light to support the inheritance of acquired character states as reported by Kammerer. His findings on color pattern change in the fire salamander have to some degree been confirmed, but a transgenerational experiment to show that they result from a fixed genetic alteration is lacking. To support Kammerer's inferences, data on geographical variation and phenotypic plasticity will not qualify, because it is the inheritance of acquired character states, as directly tractable from morphology and behavior, that is at stake. Accordingly, the "midwife toad challenge" is still out, in particular of course to those who see value in Kammerer's work.

\section{REFERENCES}

Adrian-Kalchhauser, I., Sultan, S. E., Shama, L. N., Spence-Jones, H., Tiso, S., Valsecchi, C. I., et al. (2020). Understanding 'non-genetic' inheritance: insights from molecular-evolutionary crosstalk. Trends Ecol. Evol. 35, 1078-1089. doi: 10.1016/j.tree.2020.08.011

Anastasiadi, D., Venney, C. J., Bernatchez, L., and Wellenreuther, M. (2021). Epigenetic inheritance and reproductive mode in plants and animals. Trends Ecol. Evol. 36, 1124-1140. doi: 10.1016/j.tree.2021.08.006

Attenborough, D. (2013). Natural Curiosities. A Curious Hoax? Season 1, Episode 2. Available online at: https://www.sky.com/watch/title/series/56b82eb9765e-44df-a123-be09f2504ed7/david-attenborough-s-natural-curiosities56b82eb9-765e-44df-a123-be09f2504ed7/episodes/season-1/episode- 2 (accessed May 19, 2018)

Bateson, W. (1913). Problems of Genetics. Mrs. Hepsa Ely Silliman Memorial Lectures. New Haven, CT: Yale University Press.

Bateson, W. (1919). Dr. Kammerer's testimony to the inheritance of acquired characters. Nature 103, 344-345. doi: 10.1038/103344b0

Blackburn, D. G. (2019). The oviparous olm: analysis \& refutation of claims for viviparity in the cave salamander Proteus anguinus (Amphibia: Proteidae). Zool. Anzeiger 281, 16-23. doi: 10.1016/j.jcz.2019.05.004

Buckley, D., Alcobendas, M., García-París, M., and Wake, M. H. (2007). Heterochrony, cannibalism, and the evolution of viviparity in Salamandra salamandra. Evol. Dev. 9, 105-115. doi: 10.1111/j.1525-142X.2006.00141.x

Buley, K. R., and Gonzalez-Villavicencio, C. (2000). The Durrell Wildlife Conservation Trust and the Mallorcan midwife toad, Alytes muletensis - into the 21st century. Herpetol. Bull. 72, 17-20.

Burgon, J. D., Vences, M., Steinfartz, S., Bogaerts, S., Bonato, L., DonaireBarroso, D., et al. (2021). Phylogenomic inference of species and subspecies diversity in the Palearctic salamander genus Salamandra. Mol. Phylogenet. Evol. 157:107063. doi: 10.1016/j.ympev.2020.107063

Cirino, P., Toscano, A., Caramiello, D., Macina, A., Miraglia, V., and Monte, A. (2002). Laboratory culture of the ascidian Ciona intestinalis (L.): a model system for molecular developmental biology research. Mar. Models Electron. Rec. Available online at: http://comm.archive.mbl.edu/BiologicalBulletin/MMER/ cirino/CirCon.html

Deichmann, U. (2016). Epigenetics: the origins and evolution of a fashionable topic. Dev. Biol. 416, 249-254. doi: 10.1016/j.ydbio.2016.06.005

Durand, J. P. (1976). Ocular development and involution in the European cave salamander, Proteus anguinus Laurenti. Biol. Bull. 151, 450-466. doi: 10.2307/ 1540499

Fox, H. M. (1924). Note on Kammerer's experiments with Ciona concerning the inheritance of an acquired character. J. Genet. 14, 89-91. doi: 10.1007/ BF02983085

Gliboff, S. (2005). 'Protoplasm is soft wax in our hands': Paul Kammerer and the art of biological transformation. Endeavour 29, 162-167. doi: 10.1016/j.endeavour. 2005.10.001

Gliboff, S. (2006). The case of Paul Kammerer: evolution and experimentation in the early 20th century. J. Hist. Biol. 39, 525-536. doi: 10.1007/s10739-005-3051-5

\section{AUTHOR CONTRIBUTIONS}

The author confirms being the sole contributor of this work and has approved it for publication.

\section{ACKNOWLEDGMENTS}

The author thanks the Wellcome Trust for a travel grant in 1991, that allowed him to search for remnants of Kammerer's material in natural history collections kept in Vienna and Moscow.

Gliboff, S. (2010). Did Paul Kammerer discover epigenetic inheritance? No and why not. J. Exp. Zool. Mol. Dev. Evol. 314B, 616-624. doi: 10.1002/jez.b.21374

Goldschmidt, R. B. (1956). Portraits from Memory. Recollections of a Zoologist. Seattle, WA: University of Washington Press.

Greven, H. (2003). "Larviparity and pueriparity," in Reproductive Biology and Phylogeny. Reproductive Biology and Phylogeny of Urodela, Vol. 1, ed. D. M. Sever (Enfield, NH: Science Publisher Inc), 447-475.

Herbst, C. (1924). Beiträge zur Entwicklungsphysiologie der Färbung und Zeichnung der Tiere. 2. Die Weiterzucht der Tiere in gelber und schwarzer Umgebung. Arch. Mikrosk. Anat. Entwicklungsmech. 102, 130-167. doi: 10. 1007/BF02107632

Hirschler, J. (1914). Über die Restitutions-und Involutionsvoränge bei operierten Exemplaren von Ciona intestinalis Flem. (Teil I) nebst Bemurkungen über den Wert des Negativen für das Potenzproblem. Arch. Mikrosk. Anat. 85, 205-227. doi: 10.1007/BF02981295

Jeffery, W. R. (2015). Closing the wounds: one hundred and twenty five years of regenerative biology in the ascidian Ciona intestinalis. Genesis 53, 48-65. doi: $10.1002 /$ dvg.22799

Johannsen, W. (1913). Elemente der Exakten Erblichkeitslehre, mit Grundzügen der Biologischen Variationsstatistik. Jena: Gustav Fischer Verlag.

Kammerer, P. (1904). Beitrag zur erkenntnis der verwandtschaftsverhältnisse von Salamandra atra und maculosa: experimentelle und statistische Studie. Arch. Entwicklungsmech. Org. 17, 165-264. doi: 10.1007/BF02162077

Kammerer, P. (1906). Experimentelle Veränderung der Fortpflanzungstätigkeit bei Geburtshelferkröte (Alytes obstetricans) und Laubfrosch (Hyla arborea). Arch. Entwicklungsmech. Organ. 22, 48-140. doi: 10.1007/BF02162325

Kammerer, P. (1907). Vererbung erzwungener Fortpflanzungsanpassungen. I. und II. Mitteilung: die Nachkommen der spätgeborenen Salamandra maculosa und der frühgeborenen Salamandra atra. Arch. Entwicklungsmech. Organ. 25, 7-51. doi: 10.1007/BF02292160

Kammerer, P. (1909). Vererbung erzwungener Fortpflanzungsanpassungen. III. Mitteilung: die Nachkommen der nicht brutpflegenden Alytes obstetricans. Arch. Entwicklungsmech. Organ. 28, 447-545. doi: 10.1007/BF02162072

Kammerer, P. (1910). Direkt induzierte Farbanpassungen und deren Vererbung. Vortrag, gehalten dem VII. Internationalen Zoologenkongresse zu Graz. Z. Indukt. Abstamm. Ver. 4, 279-288. doi: 10.1007/BF01730010

Kammerer, P. (1912). Experimente über Fortpflanzung, Farbe, Augen und Körperreduction bei Proteus anguinus Laur. (zugleich: Vererbung erzwungener Farbveränderungen, III. Mitteilung). Arch. Entwicklungsmech. Organ. 33, 349461. doi: 10.1007/BF02287858

Kammerer, P. (1913). Vererbung erzwungener Farbveränderungen, IV. Mitteilung: das Farbkleid des Feuersalamanders (Salamandra maculosa Laurenti) in seiner Abhängigkeit von der Umwelt. Arch. Entwicklungsmech. Organ. 36, 4-193. doi: 10.1007/BF02266717

Kammerer, P. (1915). Allgemeine Biologie. Stuttgart: Deutsche Verlags-Anstalt.

Kammerer, P. (1919). Vererbung erzwungener Formveränderungen. I. Mitteilung: Brunftschwiele der Alytes-Männchen aus „Wassereiern“ (zugleich: Vererbung erzwungener Fortpflanzungsanpassungen, V. Mitteilung.). Arch. Entwicklungsmech. Organ. 45, 323-370. doi: 10.1007/BF025 54404 
Kammerer, P. (1923). Breeding experiments on the inheritance of acquired characters. Nature 111, 637-640. doi: 10.1038/111637a0

Kammerer, P. (1924). The Inheritance of Acquired Characteristics. New York, NY: Boni and Liveright.

Knoblauch, A. (1904). Die Art der Fortpflanzung des Alpen- und des Feuersalamanders und das Anpassungsvermögen der beiden Salamanderarten an äussere Lebensbedingungen. Zool. Garten 45, 329-336, 361-368.

Koestler, A. (1971). The Case of the Midwife Toad. London: Hutchinson.

Lourenço, A., Sequeira, F., Buckley, D., and Velo-Antón, G. (2018). Role of colonization history and species-specific traits on contemporary genetic variation of two salamander species in a Holocene island-mainland system. J. Biogeogr. 45, 1054-1066. doi: 10.1111/jbi.13192

Megušar, F. (1914). Über den Einflusz äuszerer Faktoren und über Vererbung bei Krustazeen, Insekten, Mollusken und Amphibien. Verh. Ges. Dtsch. Naturforsch. Ärzte 2 Teil 1 Halfte 85, 717-719.

Nahm, M. (2021). Paul Kammerer and epigenetics - a reappraisal of his experiments. Contrib. Zool. 90, 318-343. doi: 10.1163/18759866bja10019

Parnes, O. (2006). "Paul Kammerer und die moderne Genetik. Erwerbung und Vererbung verfälschter Eigenschaften," in Fälschungen. Zu Autorschaft und Beweis in Wissenschaften und Künsten, ed. A. K. Reulecke (Frankfurt am Main: Suhrkamp), 216-243.

Redondo, A. (2012). Coros de Galanes. Alberto Redondo Documentales 22. Available online at: https://albertoredondo.tv/descubriendo-el-comportamiento-animal/ (accessed November 14, 2016).

Sanchez, E., Pröhl, H., Lüddecke, T., Schulz, S., Steinfartz, S., and Vences, M. (2019). The conspicuous postmetamorphic coloration of fire salamanders, but not their toxicity, is affected by larval background albedo. J. Exp. Zool. Part B Mol. Dev. Evol. 332, 26-35. doi: 10.1002/jez.b.22845

Schreiber, E. (1912). Herpetologia Europaea: eine Systematische Bearbeitung der Amphibien und Reptilien Welche Bisher in Europa Aufgefunden Sind. Jena: Gustav Fischer Verlag.

Schultschik, G., Schweiger, S., Mayer, C., Gassner, G., and Gollmann, G. (2017). "Data fabrication by Paul Kammerer: the testimony of Franz Megusar," in Programme and abstracts, 19th European Congress of Herpetology, 18-23 September 2017, (Salzburg: Societas Europaea Herpetologica and University of Salzburg), 143. Available online at: https://drive.google.com/ file/d/11XekvuxMwRT5eOTwwlkWVKMG_yC9TZ6_/view (accessed July 10, 2021).

Senglaub, K. (2006). Paul Kammerer (1880-1926), seine Zeit, seine Ziele und seine Züchtungsexperimente mit Feuersalamandern (Salamandra salamandra) und Geburtshelferkröten (Alytes obstetricans). Sekretär 6, 3-24.

Sermonti, G. (2000). Epigenetic heredity. In praise of Paul Kammerer. Riv. Biol. 93, 5-12.

Svardal, H. (2010). Can epigenetics solve the case of the Midwife toad? - a comment on Vargas. J. Exp. Zool. Mol. Dev. Evol. 314B, 625-628. doi: 10.1002/jez.b.21376

Taschwer, K. (2016). Der Fall Paul Kammerer. Das Abenteuerliche Leben des Umstrittensten Biologen Seiner Zeit. München: Carl Hanser. doi: 10.3139/ 9783446449411

Tonge, S., and Bloxam, Q. (1989). Breeding the Mallorcan midwife toad Alytes muletensis in captivity. Int. Zoo Yearb. 28, 45-53. doi: 10.1111/j.1748-1090. 1989.tb03251.x

van Alphen, J. J. M., and Arntzen, J. W. (2016). Paul Kammerer and the inheritance of acquired characteristics. Contrib. Zool. 85, 457-470. doi: 10.1163/1875986608504005

van Alphen, J. J. M., and Arntzen, J. W. (2017). The case of the midwife toad revisited. Contrib. Zool. 86, 261-272. doi: 10.1163/18759866-08604001
Vargas, A. O. (2009). Did Paul Kammerer discover epigenetic inheritance? A modern look at the controversial midwife toad experiments. J. Exp. Zool. Part B Mol. Dev. Evol. 312, 667-678. doi: 10.1002/jez.b.21319

Vargas, A. O., Krabichler, Q., and Guerrero-Bosagna, C. (2017). An epigenetic perspective on the midwife toad experiments of Paul Kammerer (1880-1926). J. Exp. Zool. Part B Mol. Dev. Evol. 328, 179-192. doi: 10.1002/jez.b.22708

Velo-Antón, G., García-París, M., Galán, P., and Cordero-Rivera, A. (2007). The evolution of viviparity in holocene islands: ecological adaptation versus phylogenetic descent along the transition from aquatic to terrestrial environments. J. Zool. Syst. Evol. Res. 45, 345-352. doi: 10.1111/j.1439-0469. 2007.00420.x

Velo-Antón, G., Zamudio, K. R., and Cordero-Rivera, A. (2012). Genetic drift and rapid evolution of viviparity in insular fire salamanders (Salamandra salamandra). Heredity 108, 410-418. doi: 10.1038/hdy.2011.91

Voituron, Y., de Fraipon, M., Issartel, J., Guillaume, O., and Clobert, J. (2011). Extreme lifespan of the human fish (Proteus anguinus): a challenge for ageing mechanisms. Biol. Lett. 7, 105-107. doi: 10.1098/rsbl.2010.0539

von Chauvin, M. (1876). Über die Verwandlung des mexikanischen Axolotl in Amblystoma. Z. Wissensch. Zool. 27, 522-535.

von Chauvin, M. (1877). Über das Anpassungsvermögen der Larven von Salamandra atra. Z. Wissensch. Zool. 29, 324-352.

von Chauvin, M. (1883). Die Art der Fortpflanzung des Proteus anguineus. Z. Wissensch. Zool. 38, 671-685.

von Frisch, K. (1920). Über den Einfluß der Bodenfarbe auf die Fleckenzeichnung des Feuersalamanders. Biol. Centralblatt 40, 390-414.

Weismann, A. (1892). Das Keimplasma, eine Theorie der Vererbung. Jena: Fischer Verlag.

Weissmann, G. (2012). Epigenetics in the Age of Twitter: Pop Culture and Modern Science. New York, NY: Bellevue Literary Press.

Wermel, J., and Lopaschov, G. W. (1930). Über den Einfluss der Regeneration und Überernährung auf die Siphonenlänge bei Ciona intestinalis L. Ein Beitrag zu kammerers Experimenten. Arch. Entwicklungsmech. Organ. 122, 22-47. doi: 10.1007/BF00576964

Werner, F. (1915). Einige Bemerkungen zu den salamandra-Experimenten von Šećerov und Kammerer. Biol. Centralblatt 35, 176-181.

Whittaker, J. R. (1975). Siphon regeneration in Ciona. Nature 255, 224-225. doi: $10.1038 / 255224 \mathrm{a} 0$

Whittaker, J. R. (1985). Paul Kammerer and the Suspect Siphons. MBL Science 1985: 5, 6, 16. Available online at: https://web.archive.org/web/20040305051338/ https://www.mbl.edu/publications/Ciona/Kammerer/ (accessed July 19, 2021).

Conflict of Interest: The author declares that the research was conducted in the absence of any commercial or financial relationships that could be construed as a potential conflict of interest.

Publisher's Note: All claims expressed in this article are solely those of the authors and do not necessarily represent those of their affiliated organizations, or those of the publisher, the editors and the reviewers. Any product that may be evaluated in this article, or claim that may be made by its manufacturer, is not guaranteed or endorsed by the publisher.

Copyright $(\odot 2022$ Arntzen. This is an open-access article distributed under the terms of the Creative Commons Attribution License (CC BY). The use, distribution or reproduction in other forums is permitted, provided the original author(s) and the copyright owner(s) are credited and that the original publication in this journal is cited, in accordance with accepted academic practice. No use, distribution or reproduction is permitted which does not comply with these terms. 